\title{
Granulocyte Colony-Stimulating Factor Expression from Transduced Vascular Smooth Muscle Cells Provides Sustained Neutrophil Increases in Rats
}

\author{
DANIEL V. LEJNIEKS, ${ }^{1}$ SANG WON HAN, ${ }^{1,2}$ N. RAMESH, ${ }^{1}$ STELLA LAU, ${ }^{1}$ and \\ WILLIAM R.A. OSBORNE ${ }^{1}$
}

\begin{abstract}
Granulocyte colony-stimulating factor (G-CSF) regulates granulocyte precursor cell proliferation, neutrophil survival, and activation. Cyclic hematopoiesis, a disease that occurs both in humans and grey collie dogs is characterized by cyclical variations in blood neutrophils. Although the underlying molecular defect is not known, long-term daily administration of recombinant G-CSF eliminates the severe recurrent neutropenia, indicating that expression of G-CSF by gene therapy would be beneficial. As a prelude to preclinical studies in affected collie dogs, we monitored hematopoiesis in rats receiving vascular smooth muscle cells transduced to express G-CSF. Cells transduced with LrGSN, a retrovirus expressing rat G-CSF, were implanted in the carotid artery and control animals received cells transduced with LASN, a retrovirus expressing human adenosine deaminase (ADA). Test animals showed significant increases in neutrophil counts for at least 7 weeks, with mean values of $3,670 \pm 740 \mathrm{cells} / \mu \mathrm{l}$ in comparison to $1,870 \pm 460 \mathrm{cells} / \mu \mathrm{l}$ in controls $(p<0.001)$. Thus, in rats G-CSF gene transfer targeted at vascular smooth muscle cells initiated sustained production of 1,800

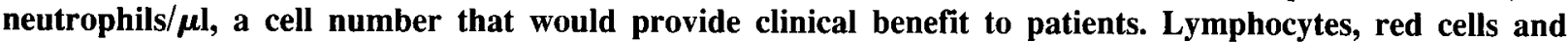
platelets were not different between control and test animals $(p>0.05)$. These studies indicate that retrovirally transduced vascular smooth muscle cells can provide sustained clinically useful levels of neutrophils in vivo.
\end{abstract}

\section{OVERVIEW SUMMARY}

Cyclic hematopoiesis is a disease that occurs both in humans and grey collie dogs and is characterized by cyclical variations in blood neutrophils. Although the underlying molecular defect is unknown, long-term daily administration of recombinant granulocyte colony-stimulating factor (G-CSF) eliminates the severe recurrent neutropenia, indicating that expression of G-CSF by gene therapy would be beneficial. In a preclinical rat model, we monitored neutrophil production in rats receiving vascular smooth muscle cells transduced to express G-CSF. Cells transduced with LrGSN, a retrovirus expressing rat G-CSF, were implanted in the carotid artery and control animals received cells transduced with LASN, a retrovirus encoding human adenosine deaminase. Test animals showed a doubling of neutrophil counts for at least 7 weeks, with mean values of
$3,670 \pm 740$ cells $/ \mu l$ in comparison to $1,870 \pm 460$ cells $/ \mu l$ in controls $(p<0.001)$. This suggests that G-CSF gene transfer targeted at vascular smooth muscle cells mediated production of 1,800 cells/ $\mu$ l, a neutrophil count that would provide clinical benefit to patients. These studies show that retrovirally transduced vascular smooth muscle cells can provide sustained clinically relevant levels of neutrophils in vivo.

\section{INTRODUCTION}

$\mathbf{G}$ RANULOCYTE COLONY-STIMULATING FACTOR (G-CSF) is a cytokine that selectively stimulates the proliferation and differentiation of neutrophil precursors and accelerates neutrophil maturation and release from the marrow (Demetri and Griffin, 1991; Morstyn and Dexter, 1993). Recently, recombi-

${ }^{1}$ Department of Pediatrics, University of Washington, Seattle, WA 98195.

${ }^{2}$ Department of Biochemistry-IB, Unesp Rio Claro-SP, 13500, Brazil. 
nant G-CSF has been used to treat chronic neutropenias of various causes to decrease morbidity and mortality due to infection (Morstyn and Dexter, 1993). Regardless of cause, treatment of neutropenic individuals with recombinant G-CSF often results in at least a partial normalization of neutrophil number and function. However, due to the symptomatic rather than curative nature of the treatment, these diseases often require lifelong daily injections with this hormone. In this category is cyclic hematopoiesis, a disease that occurs both in humans and grey collie dogs, and is characterized by cyclical variations in blood neutrophils, monocytes, lymphocytes, eosinophils, reticulocytes, and platelets due to periodic fluctuations in blood cell production by the bone marrow (Dale et al., 1972; Jones and Lange, 1983; Dale and Hammond, 1988). The recurrent severe neutropenia leads to bacterial infections and shortened life expectancy. The disorder can be cured by bone marrow transplantation in grey collie dogs as well as in humans; and in both dogs and humans the disease can be transferred from an affected to a normal (Dale and Graw, 1974; Weiden et al., 1974; Krance et al., 1982). This transplantability strongly supports the concept that this is a disease of defective regulation of hematopoietic stem cells. Although the underlying molecular defect is not known, long-term daily administration of recombinant G-CSF eliminates the severe recurrent neutropenia (Lothrop et al., 1988; Hammond et al., 1989, 1990). The constitutive expression of G-CSF by gene therapy would provide clinical and probably economic benefits.

The major colony-stimulating factors have been expressed in several cell types following gene transfer in vitro (Lang et al., 1985; Laker et al., 1987; Wong et al., 1987; Browder et al., 1989), and the retrovirus-mediated transfer and expression of interleukin-3 (IL-3) (Wong et al., 1989), granulocytemacrophage colony-stimulating factor (GM-CSF) (Johnson et al., 1989), and G-CSF (Chang et al., 1989) in mouse hematopoietic cells in vivo has been described. The retrovirally expressed IL-3 (Wong et al., 1989) and GM-CSF (Johnson et al., 1989) produced a fatal myeloproliferative syndrome in treated mice. Most noteworthy, however, long-term expression of G-CSF produced sustained neutrophilia that was not associated with disease (Chang et al., 1989). Similarly, a mouse mammary tumor constitutively expressing G-CSF produced sustained neutrophilia in mice without myeloproliferative disease (Lee and Lottsfeldt, 1984). The severe recurrent neutropenia in grey collie dogs was not abrogated by in vivo IL-3 or GM-CSF treatment (Hammond et al., 1990). IL-3 caused eosinophilia, whereas recombinant human GM-CSF caused neutrophilia and eosinophilia, but with both agents cycling of hematopoiesis persisted (Hammond et al., 1990). In contrast, G-CSF prevented the recurrent neutropenia and obliterated periodic fluctuation of monocyte, eosinophil, reticulocyte, and platelet counts (Lothrop et al., 1988; Hammond et al., 1990).

We have shown in rats long-term expression of human ADA (Lynch et al., 1992; Clowes et al., 1994) and erythropoietin (Osborne et al., 1995) from transduced smooth muscle cells seeded into carotid arteries. In vascular injury, where the vessel is not completely re-endothelialized, vascular smooth muscle cells form a pseudoendothelium that is in direct contact with the blood (Clowes et al., 1983). Vascular smooth muscle cells are readily obtained, cultured, transduced, and implanted, making these cells a generally useful target tissue for gene therapy. We recently cloned rat G-CSF (Han et al., 1996) and as a pre- lude to the treatment of collie dogs with cyclic hematopoiesis, we investigated the ability of transduced vascular smooth muscle cells to provide therapeutic levels of G-CSF in rats.

\section{MATERIALS AND METHODS}

\section{Retroviral vectors}

The G-CSF expression vector was made by digesting rat G-CSF cDNA (Han et al., 1996) with Eco RI and Dra I and ligating the isolated DNA fragment $(700 \mathrm{bp}$ ) into the viral plasmid LXSN (Miller and Rosman 1989), previously digested with Eco $\mathrm{RI}$ and $H p a$ I to provide the expression vector LrGSN. In LrGSN, rat G-CSF cDNA expression is driven by the strong viral LTR promoter and the neo resistance gene is expressed from SV-40 early region promoter/enhancer (Hock et al., 1989). From PA317 packaging cell lines (Miller and Buttimore, 1986), LrGSN had a viral titer of $8 \times 10^{6} \mathrm{cfu} / \mathrm{ml}$. The retroviral vector LASN, which encodes nonsecreted human adenosine deaminase (ADA) (Hock et al., 1989), was chosen as a control vector.

\section{Cell culture and transduction}

Ecotropic PE501 and amphotropic PA317 retrovirus packaging cell lines (Miller and Buttimore, 1986; Miller and Rosman, 1989), NIH-3T3 thymidine kinase-negative cells (Miller and Buttimore, 1986), and primary cultures of rat vascular smooth muscle cells were grown in Dulbecco/Vogt-modified Eagle's medium (DMEM) with high glucose (4.5 gram/liter) supplemented with $10 \%$ fetal bovine serum in humidified $5 \% \mathrm{CO}_{2} / 95 \%$ air at $37^{\circ} \mathrm{C}$.

Rat smooth muscle cell cultures were prepared by enzymatic digestion of the aorta from male Fisher 344 rats. These cells were characterized by positive staining for muscle cell-specific actins with HHF35 antibody (Geary et al., 1994) while staining negative for von Willebrand factor (Geary et al., 1994), an endothelial cell-specific marker. Early-passage smooth muscle cells were exposed to 16-hr virus harvests from PA317-LrGSN and PA317-LASN amphotropic virus-producing cell lines for a period of $24 \mathrm{hr}$ in the presence of Polybrene $(4 \mu \mathrm{g} / \mathrm{ml})$, and selected in $\mathrm{G} 418$ antibiotic $(1 \mathrm{mg} / \mathrm{ml})$.

\section{G*CSF bioassay}

Cytokine secretion from LrGSN-transduced cells was monitored using a murine cell line, NFS-60, that proliferates in response to G-CSF (Dale et al., 1992). Recombinant canine G-CSF (kindly supplied by Amgen, Thousand Oaks, CA) was used to construct a proliferation-response curve with murine NFS-60 cells (Dale et al., 1992). In brief, short-term proliferation was determined by measuring tritiated thymidine incorporation by cells seeded at a concentration of $10^{5}$ cells/well in 96well microtiter plates. Proliferative response to conditioned medium was measured after $24 \mathrm{hr}$ at $37^{\circ} \mathrm{C}, 5 \% \mathrm{CO}_{2}$ and harvesting the cells $4 \mathrm{hr}$ later on fiberglass filters using an automated cell harvester (Cambridge Technology, Cambridge, MA).

\section{Cell implantation}

Male Fisher 344 rats (275-325 grams) were premedicated with $0.04 \mathrm{mg} / \mathrm{kg}$ atropine subcutaneously and $2.5 \mathrm{mg} / \mathrm{kg}$ enrofloxacin 
i.m. and were anesthetized using $44 \mathrm{mg} / \mathrm{kg}$ ketamine, $5 \mathrm{mg} / \mathrm{kg}$ xylazine, and $0.5 \mathrm{mg} / \mathrm{kg}$ acepromazine i.p. Animals were placed in dorsal recumbency and an incision was made along the ventral midline of the neck from the angle of the mandible to the thoracic inlet (Clowes et al., 1994). The left common carotid and its internal and external branches were exposed using blunt dissection. Temporary ligatures were placed around the caudal common carotid artery and the cranial extent of the internal carotid. The external carotid was permanently ligated and an arterotomy made between this ligature and the bifurcation of the external and internal branches. A Fogarty $2 \mathrm{~F}$ arterial embolectomy catheter was inserted through the arteriotomy site and the interior of the common carotid was balloon injured. The balloon catheter was withdrawn and a 24-gauge angiocatheter (Becton Dickinson) was inserted. A total of $2 \times 10^{6}$ transduced vascular smooth muscle cells were introduced into the lumen of the common carotid artery and allowed to seed the artery wall for $15 \mathrm{~min}$. The angiocatheter was withdrawn and the arteriotomy site was closed by placing a second permanent ligature around the exter- nal carotid artery just caudal to the site. Blood flow was re-established through the common carotid artery and the internal carotid artery and the incision was closed.

\section{Blood counts}

Anticoagulated blood samples $(100 \mu \mathrm{l})$ were obtained from the tail vein with the animals under light ether anesthesia. Samples were obtained from 19 days before surgery and from 3 to 7 days post surgery for up to 7 weeks. Total white blood cells (WBC) platelets, and hematocrit values were determined using a Coulter T-540 counter and differential WBC counts were obtained manually.

\section{RESULTS}

We monitored NFS-60 cell proliferation in the presence of conditioned medium from PA 317-LrGSN amphotropic packaging cells and LrGSN-transduced Fisher rat vascular smooth

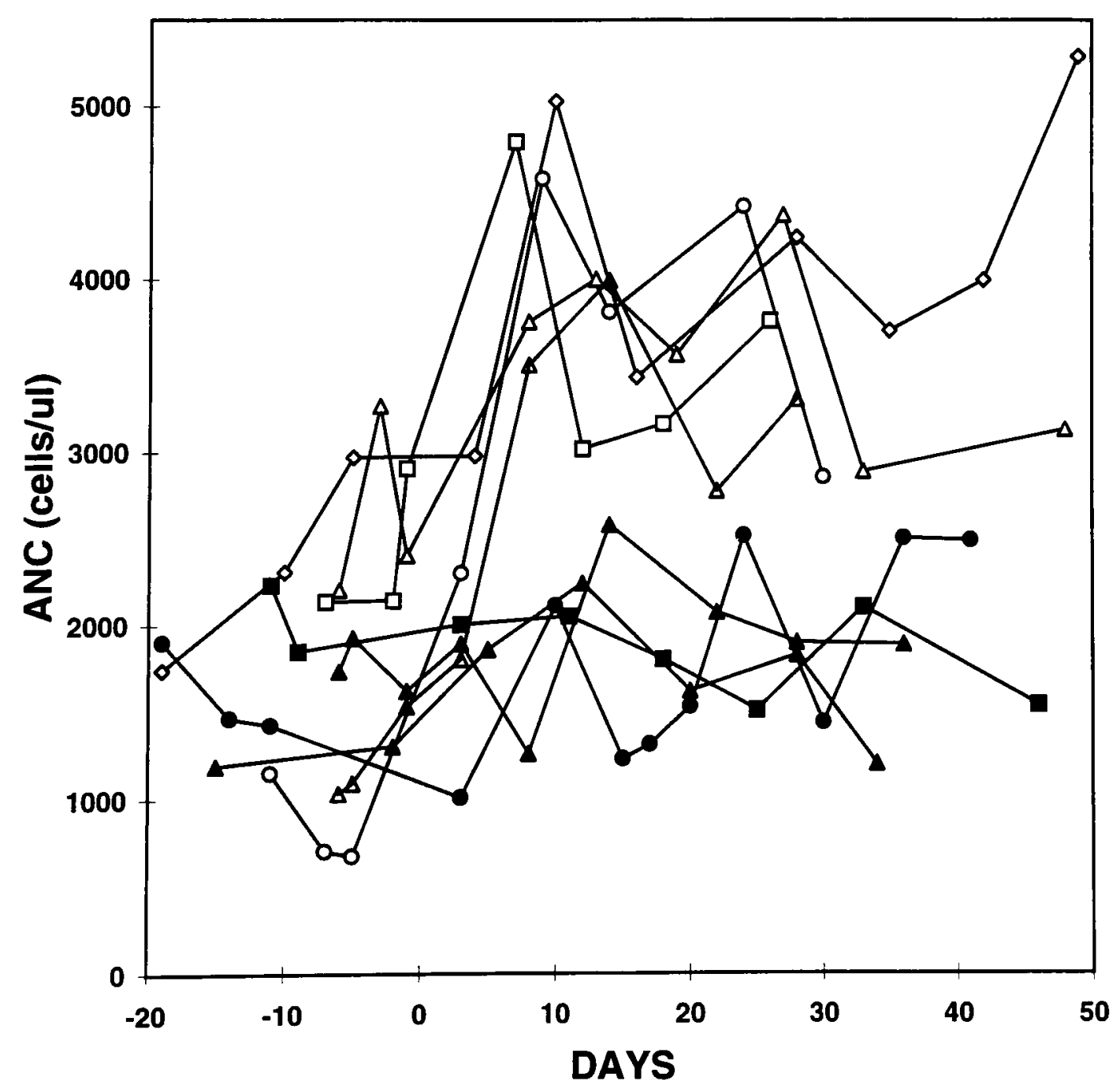

FIG. 1. Effect of seeding transduced vascular smooth muscle cells on absolute neutrophil count (ANC). Open symbols, animals implanted with LrGSN-transduced cells; solid symbols, animals receiving LASN-transduced cells. Surgery was on day zero. 
muscle cells, using PA 317-LASN packaging cells and LASNtransduced smooth muscle cells, respectively, to provide control medium. G-CSF expression was $2 \mathrm{ng} / 24$ hr per $10^{7}$ cells from packaging cells and $8 \mathrm{ng} / 24 \mathrm{hr}$ per $10^{7}$ cells from transduced smooth muscle cells. These assays indicate expression of a bioactive gene product from our retroviral vector, but are probably an underestimate because purified rat G-CSF was not available and recombinant canine G-CSF was used to generate a standard curve.

The absolute neutrophil counts of animals receiving LrGSNtransduced cells increased rapidly after cell implantation, and by day 10 a relatively constant elevated plateau had been achieved which was sustained for at least 7 weeks (Fig. 1). In contrast, neutrophil counts obtained before and after surgery from animals seeded with LASN-transduced cells did not show changes (Fig. 1). This suggests that the consequences of surgery were not responsible for the increased number of neutrophils observed in the test rats. The surgical procedure was well tolerated by the animals, with no evidence of fever or other malaise, and this may be reflected in the lack of neutrophil increases in animals receiving LASN-transduced cells. Pooled hematopoietic cell data from 6 control and 8 test rats are shown in Table 1. Neutrophil counts recorded from rats after LrGSNcell implantation were significantly elevated over control rats receiving LASN-transduced cells $(p<0.001)$. A similar statistical comparison of platelets, lymphocytes, and red cells, as measured by hematocrit, showed no significant differences $(p>0.05$ ). This is noteworthy as previous studies of G-CSF administration to mice have shown reduction in red cell numbers (Molineux et al., 1990; Pojda et al., 1990).

\section{DISCUSSION}

We have shown that retrovirally transduced vascular smooth muscle cells allow sustained expression of G-CSF that stimulated significantly elevated neutrophil production for periods of up to 7 weeks. In treated rats, we documented mean increases of 1,800 neutrophils $/ \mu l$, which would be a therapeutic cell number for patients with severe chronic neutropenia or cyclic hematopoiesis. In these patients and cyclic neutropenic dogs, provision of neutrophil counts in excess of $500 / \mu \mathrm{l}$ prevent severe recurrent infection and would be therapeutic (Lothrop et al., 1988; Hammond et al., 1989; Morstyn and Dexter, 1993).

We observed no significant differences in lymphocyte and platelet numbers and hematocrit between animals treated with
G-CSF-expressing cells and controls, indicating vector-encoded G-CSF production stimulated neutrophil production without other hematological effects. This is of interest because previous studies in mice have shown that G-CSF administration caused reduced erythropoiesis and anemia (Molineux et al., 1990; Pojda et al., 1990). Because long-term administration of recombinant G-CSF to humans (Morstyn et al., 1988; Morstyn and Dexter, 1993) and dogs (Hammond et al. 1989, 1990) specifically stimulates neutrophil production, our data suggest that rats provide a more appropriate human model for the physiological study of G-CSF administration than mice. G-CSF expression, unlike GM-CSF (Johnson et al., 1989) and IL-3 (Wong et al., 1989), did not cause pathological changes in hematopoiesis. In previous studies, these latter cytokines produced a fatal myeloproliferative syndrome in mice (Johnson et al., 1989; Wong et al., 1989).

The implantation of genetically modified vascular smooth muscle cells to patients will require an approach other than arterial seeding. Recently, we proposed the seeding of synthetic PTFE (polytetrafluoroethylene) grafts as a method to return transduced vascular smooth muscle cells to their donor (Geary et al., 1994) and this technique can be readily studied in collie dogs with cyclic hematopoiesis, an appropriate clinical model for affected patients (Dale et al., 1988; Lothrop et al., 1988). We have shown that the rat carotid artery seeding procedure resulted in approximately $10^{5}$ cells being retained within the artery (Osborne et al., 1995). On the basis of this finding, we estimate that the potentially therapeutic level of neutrophils we observed in rats was derived from $10^{5}$ transduced cells. We previously estimated that $10^{8}$ transduced cells can be seeded into a 10-cm $\times$ 4-mm PTFE graft (Osborne et al., 1993; Geary et al. 1994) and from the current study, this should provide a therapeutic level of G-CSF to a dog. It is also probable that neutropenic dogs and patients are more sensitive to G-CSF than normals.

Our data show that transduced vascular smooth muscle cells do not inactivate retroviral vector sequences, in agreement with previous studies of retrovirally mediated gene expression in these target cells (Lynch et al., 1992; Clowes et al., 1994; Osborne et al., 1995). This is in contrast to skin fibroblasts where vector inactivation has been documented in both rats (Palmer et al., 1991) and dogs (Ramesh et al., 1993). Thus, data is accumulating to show that vascular smooth muscle cells provide an ideal target tissue for gene therapy. These cells are readily obtained, cultured, transduced, and returned to their donor. Implantation of these cells in the blood circulation suggests that their use for the secretion of not only hormones but also clot-

Table 1. Control and Treated Rat Blood Counts

\begin{tabular}{lllllc}
\hline & $\begin{array}{c}\text { Neutrophils } \\
\text { per } \mu l\end{array}$ & $\begin{array}{c}\text { Lymphocytes } \\
\text { per } \mu l\end{array}$ & HCT & $\begin{array}{c}\text { Platelets per } \mu l \\
\left(\times 10^{-3}\right)\end{array}$ \\
\hline LASN & Pre-surgery & $1,850 \pm 390$ & $6,870 \pm 1,180$ & $43.7 \pm 2.84$ & $673 \pm 167$ \\
$(n=6)$ & Post-surgery & $1,870 \pm 460^{\mathrm{a}}$ & $6,180 \pm 970^{\mathrm{b}}$ & $45.0 \pm 2.22^{\mathrm{b}}$ & $716 \pm 96^{\mathrm{b}}$ \\
LrGSN & Pre-surgery & $1,880 \pm 750$ & $6,470 \pm 1,140$ & $44.3 \pm 2.38$ & $678 \pm 122$ \\
$(n=8)$ & Post-surgery & $3,670 \pm 740^{\mathrm{a}}$ & $6,240 \pm 1,300^{\mathrm{b}}$ & $43.9 \pm 1.55^{\mathrm{b}}$ & $704 \pm 94^{\mathrm{b}}$ \\
\hline
\end{tabular}

${ }_{b}^{a} p<0.001$
${ }^{a} p>0.05$ 
ting factors for the treatment of patients with hemophilia and enzymes for treatment of lysosomal storage disorders.

\section{ACKNOWLEDGMENTS}

We thank Dr. David Dale for many helpful discussions. This work was supported by grants DK 43727 and DK 47754 from the National Institutes of Health.

\section{REFERENCES}

BROWDER, R.M., ABRAMS, J.S., WONG, P.M.C., and NIENHUIS A.W. (1989). Mechanism of autocrine stimulation in hematopoietic cells producing interleukin-3 after retrovirus-mediated gene transfer. Mol. Cell. Biol. 9, 204-213.

CHANG, J.M., METCALF, D., GOUDA, T.J., and JOHNSON, G.R. (1989). Long-term exposure to retrovirally expressed granulocytecolony-stimulating factor induces a non-neoplastic granulocytic and progenitor cell hyperplasia without tissue damage in mice. J. Clin. Invest. 84, 1488-1496.

CLOWES, A.W., REIDY, M.A., and CLOWES, M.M. (1983). Kinetics of cellular proliferation after arterial injury: 1 . Smooth muscle growth in the absence of endothelium. Lab Investigation 49, 327-333.

CLOWES, M.M., LYNCH, C.M., MILLER, A.D., MILLER, D.G., OSBORNE, W.R.A., and CLOWES, A.W. (1994). Long-term biological response of injured rat carotid artery seeded with smooth muscle cells expressing retrovirally introduced human genes. J. Clin. Invest. 93, $644-651$.

DALE, D.C., and GRAW, R. (1974). Transplantation of allogeneic bone marrow in canine cyclic neutropenia. Science 183, 83-84.

DALE, D.C., and HAMMOND, W.P. (1988). Cyclic neutropenia: A Clinical review. Blood Rev. 2, 178-185.

DALE, D.C., WARD, S.B., KIMBALL, H.R., and WOLFF, S.M. (1972). Studies on neutrophil production and turnover in grey collie dogs with cyclic neutropenia. J. Clin. Invest. 51, 2190-2196.

DALE, D.C., LAU, S., NASH, R., BOONE, T., and OSBORNE, W.R. (1992). Effect of endotoxin on serum granulocyte and granulocytemacrophage colony-stimulating factor levels in dogs. J. Infect. Dis. $165,689-694$.

DEMETRI, G.D., and GRIFFIN, J.D. (1991). Granulocyte colony-stimulating factor and its receptor. Blood 78, 2791-2808.

GEARY, R.L., CLOWES, A.W., LAU, S., VERGEL, S., DALE, D.C., and OSBORNE, W.R.A. (1994). Gene transfer in baboons using prosthetic vascular grafts seeded with retrovirally-transduced smooth muscle cells: A model for local and systemic gene therapy. Hum. Gene Ther. 5, 1213-1218.

HAMMOND, W.P., PRICE, T.H., SOUZA, L.M., and DALE, D.C. (1989). Treatment of cyclic neutropenia with granulocyte colonystimulating factor. N. Engl. J. Med. 320, 1306-1311.

HAMMOND, W.P., BOONE, T.C., DONAHUE, R.E., SOUZA, L.M., and DALE, D.C. (1990). A comparison of treatment of canine cyclic hematopoiesis with recombinant human G-CSF, GM-CSF, and IL-3 and canine G-CSF. Blood 76, 523-532.

HAN, W.S., RAMESH, N., and OSBORNE, W.R.A. (1996). Cloning and expression of the cDNA encoding rat granulocyte colony-stimulating factor. Gene (in press).

HOCK, R.A., MILLER, A.D., and OSBORNE, W.R.A. (1989). Expression of human adenosine deaminase from various strong promoters after gene transfer into human hematopoietic cell lines. Blood 74, 876-881.

JOHNSON, G.R., GONDA, R.J., METCALF, D., HARIHARAN, I.K., and CORY, S. (1989). A lethal myeloproliferative syndrome in mice transplanted with bone marrow cells infected with a retrovirus expressing granulocyte-macrophage colony-stimulating factor. EMBO J. 8, 441-448.

JONES, J.B., and LANGE, R.D. (1983). Cyclic hematopoiesis: Animal models. Exp. Hematol. 11, 571-580.

KRANCE, R.A., SPRUCE, W.E., FORMAN, S.J., ROSEN, R.B., HECHT, T., HAMMOND, W.P., and BLUME, K.G. (1982). Human cyclic neutropenia transferred by allogeneic bone marrow grafting. Blood 60, 1263-1266.

LAKER, C., STOCKING, C., BERGHOLZ, U., HESS, N., DELAMARTER, J.F., and OSTERTAG, W. (1987). Autocrine stimulation after transfer of the granulocyte-macrophage colony-stimulating factor gene and autonomous growth are distinct but interdependent steps in the oncogenic pathway. Proc. Natl. Acad. Sci. USA 84, 8458-8462.

LANG, R.A., METCALF, D., GOUGH, N.M., DUNN, A.R., and GOUDA, R.J. (1985). Expression of a hematopoietic growth factor cDNA in a factor-dependent cell line results in autonomous growth and tumorigenicity. Cell 43, 531-542.

LEE, M.Y., and LOTTSFELDT, J.L. (1984). Augmentation of neutrophilic granulocyte progenitors in the bone marrow of mice with tumor-induced neutrophilia: Cytochemical study of in vitro colonies. Blood 65, 499-506.

LOTHROP, C.D., WARREN, D.J., SOUZA, L.M., JONES, J.B., and MOORE, M.A.S. (1988). Correction of cyclic hematopoiesis with recombinant human granulocyte colony-stimulating factor. Blood $\mathbf{7 2}$, 1324-1328.

LYNCH, C.M., CLOWES, M.M., OSBORNE, W.R.A., CLOWES, A.W., and MILLER, A.D. (1992). Long-term expression of human adenosine deaminase in vascular smooth muscle cells of rats: A model for gene therapy. Proc. Natl. Acad. Sci. USA 89, 1138-1142.

MILLER, A.D., and BUTTIMORE, C. (1986). Redesign of retrovirus packaging cell lines to avoid recombination to helper virus production. Mol. Cell. Biol. 6, 2895-2902.

MILLER, A.D., and ROSMAN, G.J. (1989). Improved retroviral vectors for gene transfer and expression. BioTechniques 7, 980-990.

MOLINEUX, G., POJDA, Z., and DEXTER, T.M. (1990). A comparison of hematopoiesis in normal and splenectomized mice treated with granulocyte colony-stimulating factor. Blood 75, 563-569.

MORSTYN, G., and DEXTER, T.M. (1993). Filgrastim (r-metHuGCSF) in clinical practice. In Basic and Clinical Oncology. (Marcel Dekker, New York) p. 351

MORSTYN, G., SOUZA, L.M., KEECH, J., SHERIDAN, W., CAMPBELL, L., ALTON, N.K., GREEN, M., METCALF, D., and FOX, R. (1988). Effect of granulocyte colony stimulating factor on neutropenia induced by cytotoxic chemotherapy. Lancet 1 , 667-672.

OSBORNE, W.R.A., GEARY, R., LAU, S., DALE, D.C.D., and CLOWES, A.W. (1993). Transduced vascular smooth muscle cells in a canine model of gene therapy. Clin. Res. 41, 194A.

OSBORNE, W.R.A., RAMESH, N., LAU, S., CLOWES, M.M., DALE, D.C., and CLOWES, A.W. (1995). Gene therapy for longterm expression of erythropoietin in rats. Proc. Natl. Acad. Sci. USA 92, 8055-8058.

PALMER, T.D., ROSMAN, G.J., OSBORNE, W.R.A., and MILLER, A.D. (1991). Genetically-modified skin fibroblasts persist long after transplantation but gradually inactivate introduced genes. Proc. Natl. Acad. Sci. USA 88, 1330-1334.

POJDA, Z., MOLINEUX, G., and DEXTER, T.M. (1990). Hematopoietic effects of short-term in vivo treatment of mice with various doses of rhG-CSF. Exp. Hematol. 18, 27-31.

RAMESH, N., LAU, S., PALMER, T.D., STORB, R., and OSBORNE, W.R.A. (1993). High-level human adenosine deaminase expression in dog skin fibroblasts is not sustained following transplantation. Hum. Gene Ther, 4, 3-7.

WEIDEN, P.L., ROBINETT, B., GRAHAM, T.C., ADAMSON, J., and 
STORB, R. (1974). Canine cyclic neutropenia. A stem cell defect. J. Clin. Invest. 35, 950-953.

WONG, P.M.C., CHUNG, S.-W., and NIENHUIS, A.W. (1987). Retroviral transfer and expression of the interleukin-3 gene in hemopoietic cells. Genes \& Dev. 1, 358-365.

WONG, P.M.C., CHUNG, S.-W., DUNBAR, C.E., BODINE, D.M., RUSCETTI, S., and NIENHUIS, A.W. (1989). Retrovirus-mediated transfer and expression of the interleukin-3 gene in mouse hematopoietic cells results in a myeloproliferative disorder. Mol. Cell. Biol. 9, 798-808.
Address reprint requests to:

Dr.W.R.A. Osborne

Department of Pediatrics, MS 356320

University of Washington

Seattle, WA 98195

Received for publication Feb. 5, 1996; accepted after revision April 17, 1996. 